Article

\title{
Effect of Vacuum Heat Treatment on the High-Temperature Oxidation Resistance of NiCrAlY Coating
}

\author{
Jiahui Zheng, Deming Yang * and Yang Gao \\ Department of materials science and Engineering, Dalian Maritime University, Dalian 116026, China; \\ zjh199669@dlmu.edu.cn (J.Z.); gaoyang@dlmu.edu.cn (Y.G.) \\ * Correspondence: yangdeming@dlmu.edu.cn
}

Received: 13 October 2020; Accepted: 10 November 2020; Published: 13 November 2020

\begin{abstract}
NiCrAlY coatings were prepared using high-velocity oxygen fuel spraying (HVOF), and the coatings were removed from the substrate to achieve a uniform shape. Vacuum heat treatment (VHT) of the as-sprayed coatings was conducted at different temperatures $\left(1000,1100\right.$, and $\left.1200^{\circ} \mathrm{C}\right)$, and the specimens were subjected to isothermal oxidation exposure testing in air at $1100{ }^{\circ} \mathrm{C}$ for up to $21 \mathrm{~h}$. The results show that the high temperature oxidation resistance of the coating increased gradually with the increase in VHT temperature, and the coating of VHT1200 had higher oxidation resistance. The high temperature oxidation resistance of the coating was related to the microstructure transformation of the coating. In VHT coatings, $\beta$-NiAl became a dispersed irregular block morphology. The $\gamma^{\prime}-\mathrm{Ni}_{3} \mathrm{Al}$ in VHT1000 presented a granular morphology. However, in VHT1100 and VHT1200, $\gamma^{\prime}-\mathrm{Ni}_{3} \mathrm{Al}$ became a lamellar morphology. This transformation of microstructure promotes the form of exclusive $\alpha-\mathrm{Al}_{2} \mathrm{O}_{3}$ scale. With the increase in VHT temperature, the content of yttrium on coatings' surface was increased and the pores were gradually eliminated. The concentration of yttrium on coatings' surface prevented the formation of $\theta-\mathrm{Al}_{2} \mathrm{O}_{3}$ and low porosity was beneficial in improving the internal oxidation of the coating.
\end{abstract}

Keywords: vacuum heat treatment; HVOF; NiCrAlY; $\beta-\mathrm{NiAl} ; \gamma^{\prime}-\mathrm{Ni}_{3} \mathrm{Al}$; high-temperature oxidation resistance

\section{Introduction}

To improve the efficiency of aviation turbine engines, the hot components must endure an extreme environment, including high temperature and pressure. Therefore, an advanced thermal barrier coating technology is required. The thermal barrier coating consists of two parts: a ceramic thermal barrier coating and a bond coat. MCrAlY $(\mathrm{M}=\mathrm{Ni}, \mathrm{Co}, \mathrm{NiCo})$ coatings have been widely used as a bond coat for thermal barrier coatings or as a high-temperature protective coating alone [1-8]. The advantages of MCrAlY coatings have been researched by Saeidi et al. [6].

Methods for the deposition of MCrAlY coatings include electron beam physical vapor deposition, electroplating, and thermal spraying [3]. In particular, high-velocity oxygen fuel (HVOF) spraying is the most widely used technique [3,6]. During the HVOF process, powder particles have a high velocity, short exposure time and low temperature in the jet; these properties can substantially reduce the oxygen content and porosity of MCrAlY coatings to enhance their high-temperature oxidation resistance [9]. HVOF spraying is also considerably cheap and easy to operate [2,3].

MCrAlY coatings normally include NiCoCrAlY, CoCrAlY, and NiCrAlY. The properties of NiCoCrAlY and CoCrAlY with certain cobalt show much more hot corrosion resistance than that of NiCrAlY coatings under the environment of salt contaminants [10]. The composition of NiCrAlY 
coatings, which often have high nickel, chromium, and aluminum contents, is designed for nickel-based superalloys to endure high-temperature oxidation. At a temperature range of 900 to $1300{ }^{\circ} \mathrm{C}$, NiCrAlY coatings react with oxygen and form an oxide scale - thermally grown oxide (TGO)—on the surface, which will prevent the substrate from being oxidized [9]. The main TGO component is $\alpha-\mathrm{Al}_{2} \mathrm{O}_{3}$, which is slow growing and thermodynamically stable and is formed via diffusion of $\mathrm{Al}^{3+}$ inside the coating on the surface and its reaction with oxygen [11]. However, the presence of other oxides, such as spinel oxides $\left(\mathrm{Ni}(\mathrm{Cr}, \mathrm{Al})_{2} \mathrm{O}_{4}, \mathrm{NiO}, \mathrm{Cr}_{2} \mathrm{O}_{3}\right)$ and metastable $\mathrm{Al}_{2} \mathrm{O}_{3}\left(\theta-\mathrm{Al}_{2} \mathrm{O}_{3}\right)$ will accelerate the TGO growth rate and degradation of NiCrAlY coatings [9,12].

The oxidation resistance of NiCrAlY coatings is considerably affected by the thermal spray powder composition, the parameters of thermal spraying, the microstructure of the coatings, and the parameters of the processing technology $[8,13]$. In the early stage of oxidation, a pure, continuous, and dense $\alpha-\mathrm{Al}_{2} \mathrm{O}_{3}$ scale on the surface of deposited coatings can remarkably improve the oxidation resistance of NiCrAlY coatings [10]; thus, much research has been attempted, including the addition of reactive elements, such as $\mathrm{Pt} \mathrm{Cr} \mathrm{Zr}$, Hf, and Ta [14,15], the use of cryomilled powder [16,17], and the application of laser treatment on the surface of deposited coatings [18]. Recent studies have shown that vacuum heat treatment (VHT) can affect the oxidation resistance of MCrAlY coatings. Doolabi et al. [9] reported that VHT decreased the oxidation resistance of CoNiCrAlY because VHT transformed the coating microstructure from a single $\gamma$-NiAl phase to a two-phase $\gamma+\beta$. The two-phase microstructure, together with coarse grain size and low dislocation density, of VHT coatings reduced the aluminum diffusion rate and decreased the possibility of having a single layer of alumina. On the contrary, Han [10] showed a different conclusion. VHT could improve the high-temperature oxidation resistance of CoCrAlY coating, due to the tensile stress in the TGO of the VHT coating decreasing, which might reduce the TGO growth rate and the spinel oxide generated on the surface of the VHT coating. Currently, few people have researched the effect of the change in temperature of VHT on the oxidation resistance of MCrAlY.

This study aimed to investigate the changes in coating microstructure under different VHT temperatures and explore the effects of these changes on the high temperature oxidation in the early stage of HVOF NiCrAlY coatings. The microstructural evolution of the coatings under different VHT conditions was analyzed, and the process parameters of VHT were comparatively optimized.

\section{Materials and Methods}

\subsection{Powder Material}

The powder used in this study was a NiCrAlY alloy powder produced by H.C. Starck (AMPERT 413 , Munich, Germany). The powder is a type of spherical powder with a size range of 15 to $45 \mu \mathrm{m}$, and the average powder particle size is $22 \mu \mathrm{m}$. The morphology of the powder is shown in Figure 1 . The nominal chemical composition of the powder is listed in Table 1.

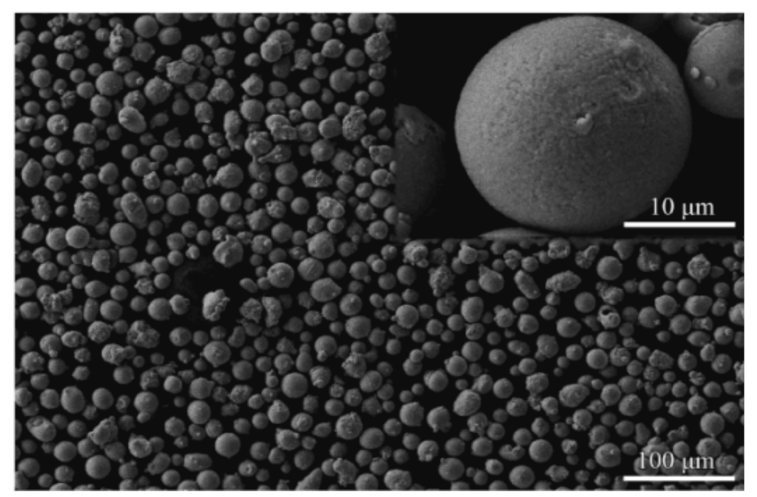

Figure 1. The microstructure of the NiCrAlY powder used for high-velocity oxygen fuel spraying (HVOF) spraying. 
Table 1. Chemical composition of feedstock powder (wt.\%).

\begin{tabular}{ccccc}
\hline Element & Ni & $\mathbf{C r}$ & $\mathbf{A l}$ & $\mathbf{Y}$ \\
\hline Content & 67 & 22 & 10 & 1 \\
\hline
\end{tabular}

\subsection{Sample Preparation}

The NiCrAlY coatings were deposited on $\mathrm{FeCrAl}$ alloy using an HVOF process (Sulzer Metco DJ2700, Winterhur, Switzerland). Table 2 lists the spraying parameters used in this study. To obtain a free-standing coating, the sandblasting was skipped before spraying to reduce the bonding strength of the coating. Due to the low bonding strength, the coating was separated from the substrate by bending it around a mandrel of a thickness of approximately $0.8 \mathrm{~mm}$ when it was being sprayed. The free-standing coating was then cut into $15 \mathrm{~mm} \times 15 \mathrm{~mm} \times 0.5 \mathrm{~mm}$ pieces by using a surface grinder and a cutter. The surfaces of the pieces were polished to metallic luster by using sandpaper (360 mesh).

Table 2. HVOF spraying parameters of NiCrAlY coatings.

\begin{tabular}{cc}
\hline Parameters & Values \\
\hline $\mathrm{O}_{2}$ & $10.3 \mathrm{bar}, 240 \mathrm{~L} / \mathrm{min}$ \\
$\mathrm{C}_{3} \mathrm{H}_{8}$ & $6.2 \mathrm{bar}, 58 \mathrm{~L} / \mathrm{min}$ \\
Air & $6.9 \mathrm{bar}$ \\
Spray distance & $230 \mathrm{~mm}$ \\
Powder feeding rate & $35 \mathrm{~g} / \mathrm{min}$ \\
\hline
\end{tabular}

\subsection{VHT}

The VHT furnace (Weike, VHA-150/200, Shengyang, China) $\left(<5 \times 10^{-2} \mathrm{~Pa}\right.$, Air) was heated to 1000,1100 , and $1200^{\circ} \mathrm{C}$ for $2 \mathrm{~h}$, and the heat rate was set to $10^{\circ} \mathrm{C} / \mathrm{min}$ from ambient and cooled with the furnace. The samples were marked as shown-VHT1000, VHT1100 and VHT1200. Six samples were treated in each batch of VHTs. Three samples were used for the oxidation test and other samples were used for characterization research. The maximum heating temperature of the furnace is $1500{ }^{\circ} \mathrm{C}$, and the size of the effective heating zone is $150 \mathrm{~mm} \times 120 \mathrm{~mm} \times 200 \mathrm{~mm}$.

\subsection{High-Temperature Oxidation Test}

All of the specimens were subjected to a high-temperature oxidation test in a muffle furnace (Xinyu, XY-1700, Nanyang, China). The high-temperature oxidation test was conducted at $1100{ }^{\circ} \mathrm{C}$ for $21 \mathrm{~h}$ in air. The weight gain of the coatings was measured using an analytical balance of $0.1 \mathrm{mg}$ precision at $1,6,11,16$, and $21 \mathrm{~h}$, and a weight gain curve was drawn.

\subsection{Sample Characterization}

The phase identification of the specimens was performed via X-ray diffractometer (XRD) (Rigaku, D/Max-Ultima+, Tokyo, Japan, $\mathrm{Cu} \mathrm{K} \alpha$ ). The scanning speed was $8^{\circ} / \mathrm{min}$, and the $2 \theta$ values ranged from $20^{\circ}$ to $95^{\circ}$. The phase compositions were analyzed using Jade (Intelligent XRD Analysis Software, Material Data TM, Version: 6). The cross-sectional and surface microstructures of the samples were evaluated by SEM (Supra 55, Carl Zeiss, Oberkochen, Germany). The microporosity of the coating was evaluated by image analysis using OLYCIA m3 software (Version: $\mathrm{m} 3$ ), and the porosity was calculated from a larger area. The chemical composition of the samples was studied by an energy spectrometer (EDS) (Oxford X-Max Extreme, Abingdon, UK). 


\section{Results}

\subsection{Microstructure of As-Sprayed and VHT Coatings}

The phase composition was identified from the XRD result, as shown in Figure 2. Figure 3 depicts a two-phase microstructure in thermal spray powder. The $\beta-\mathrm{NiAl}$ phase (gray) is distributed on the $\gamma$-NiCr phase (white) matrix.

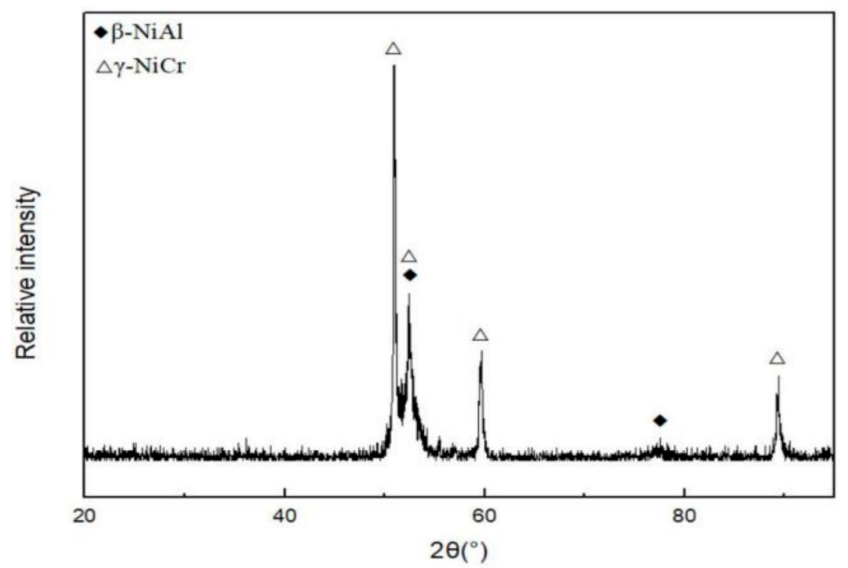

Figure 2. XRD diffractogram of feedstock NiCrAlY powder.
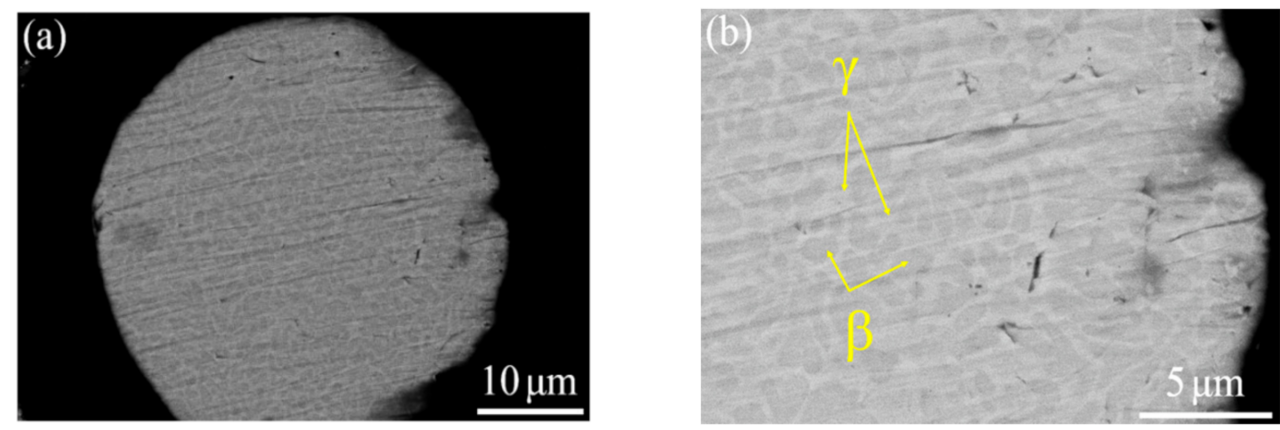

Figure 3. Cross-sectional microstructure of NiCrAlY powder at (a) low (2000×) and (b) high magnifications (5000×).

The microstructure of the as-sprayed and VHT coatings is shown in Figure 4. Figure 4a illustrates high porosity. The as-sprayed coating accumulated unmelted powders, and the microstructure of unmelted powders was the same as that of the powder. Figure $4 \mathrm{~b}-\mathrm{d}$, respectively, present the microstructure of VHT1000, VHT1100 and VHT1200 coatings. The porosity of the VHT coating is shown in Table 3, compared with the microstructure of the as-sprayed coating, the porosity considerably decreased. The $\beta-\mathrm{NiAl}$ became highly discrete, and its morphology changed as the VHT temperature increased (Figure $4 \mathrm{~b}-\mathrm{d}$ ). The $\beta-\mathrm{NiAl}$ in the as-sprayed coating exhibited a globular or ellipsoid morphology, the same as that in the powder (Figure 4a). After VHT, some irregular block $\beta-\mathrm{NiAl}$ phases appeared in the coating (Figure $4 \mathrm{c}, \mathrm{d}$ ). The new phase of $\gamma^{\prime}-\mathrm{Ni}_{3} \mathrm{Al}$ (gray) was generated in VHT coatings. In VHT1000, $\gamma^{\prime}-\mathrm{Ni}_{3} \mathrm{Al}$ presented a granular morphology. In VHT1100 and VHT1200, the morphology of $\gamma^{\prime}-\mathrm{Ni}_{3} \mathrm{Al}$ changed to a lamellar morphology.

Table 3. The porosity of the as-sprayed coating and VHT coatings.

\begin{tabular}{ccccc}
\hline Coating & As-Sprayed & VHT1000 & VHT1100 & VHT1200 \\
\hline porosity $(\%)$ & 9.4 & 0.4 & 0.2 & 0.2 \\
\hline
\end{tabular}



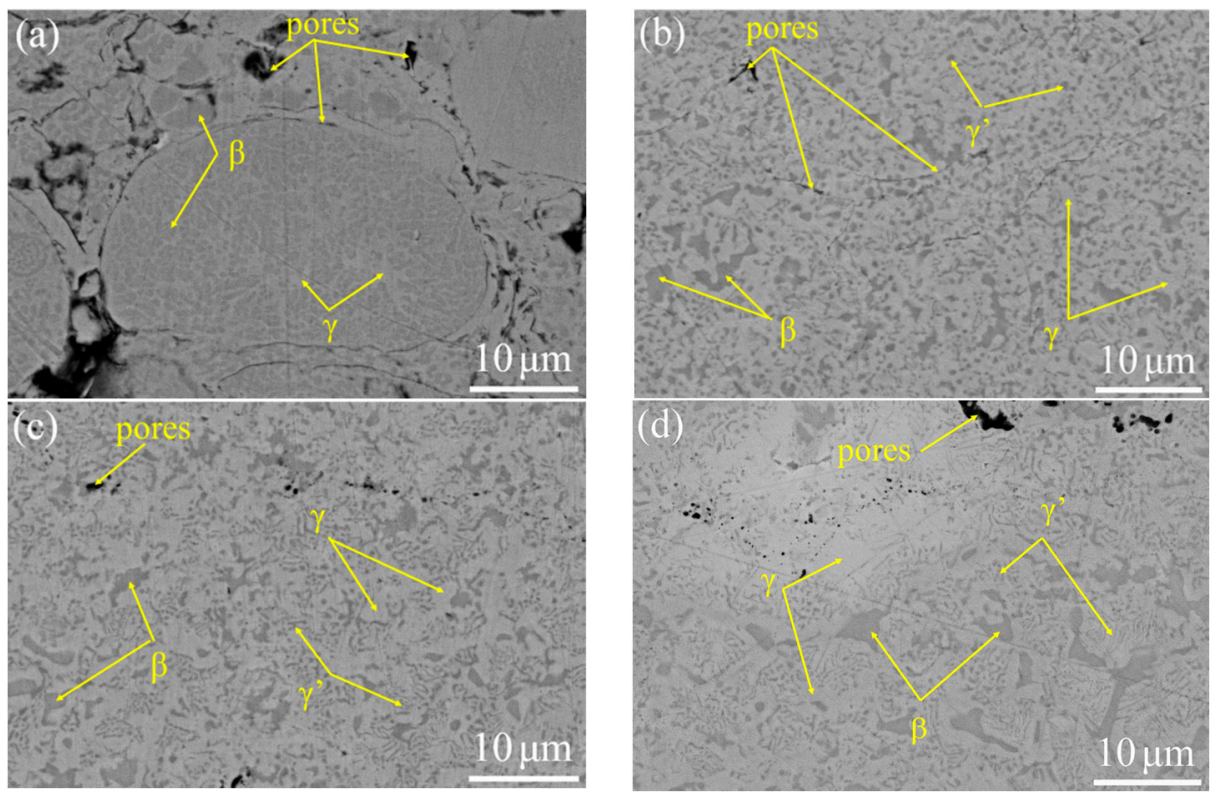

Figure 4. Internal microstructure of the as-sprayed and prepared coatings after vacuum heat treatment (VHT) at different temperatures. (a) As-sprayed, (b) VHT1000, (c) VHT1100, and (d) VHT1200.

\subsection{Weighing Results}

The results of the mass gain of oxidized samples were unified per unit area. The curve of average mass change versus time is plotted in Figure 5a. In the early stage of oxidation, the mass gains of the as-sprayed coating and VHT1000 were extremely high. However, the oxidation rate was relatively slow in the subsequent oxidation process. The mass gain of VHT1000 was slightly lower than that of the as-sprayed coating. A semiparabolic mass gain was observed for VHT1100 and VHT1200 with increasing time. The parabolic trend of mass gain in VHT1200 was reduced compared with that in VHT1100, which indicated a lower rate of mass gain and higher oxidation resistance.
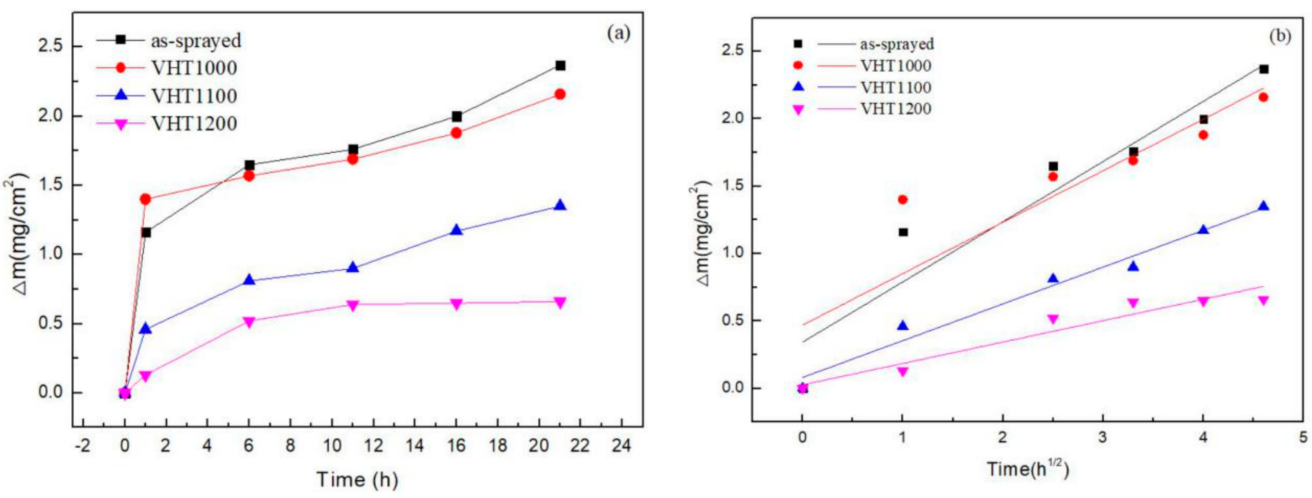

Figure 5. Weight gain data of the as-sprayed coating and VHT coatings after $21 \mathrm{~h}$ oxidation (a) original curve (b) fitting curve.

According to parabolic law:

$$
\Delta \mathrm{m}=\left(\mathrm{k}_{\mathrm{p}} \times \mathrm{t}\right)^{1 / 2}
$$

where $\Delta \mathrm{m}$ is the weight gain, $\mathrm{g} ; \mathrm{k}_{\mathrm{p}}$ is the rate constant, $\mathrm{mg}^{2} \cdot \mathrm{cm}^{-4} \cdot \mathrm{h}^{-1} ; \mathrm{t}$ is the oxidation time, $\mathrm{h}$. $\Delta \mathrm{m}$ shows a linear correlation of $\mathrm{t}^{1 / 2}$ and the rate constant corresponds to the slope of the fitted curve. The fitted results are listed in Table 4. The fitting curve is shown in Figure $5 b$. The value of $k_{p}$ is proportional to the oxidation rate; therefore, VHT1200 has the minimum rate constant, which means the lowest oxidation rate. 
Table 4. Parabolic rate constant of coatings oxidized at $1100{ }^{\circ} \mathrm{C}$.

\begin{tabular}{ccccc}
\hline Coating & As-Sprayed & VHT1000 & VHT1100 & VHT1200 \\
\hline $\mathrm{k}_{\mathrm{p}}$ & 0.45 & 0.38 & 0.27 & 0.16 \\
\hline
\end{tabular}

\subsection{Microstructure of Coatings after Oxidation}

The cross-sectional microstructures of four different coatings after $21 \mathrm{~h}$ oxidation are illustrated in Figure 6. The internal oxide (black area) of the VHT coatings was significantly less than that of the as-sprayed coating. Specifically, VHT1200 contained the least amount of internal oxide. Furthermore, several large areas of the coatings' cross section were selected for EDS. The quantitative analysis results are shown in Table 5. VHT1200 contained the minimal oxygen content, and the oxygen content in coatings decreased with the rise in temperature.
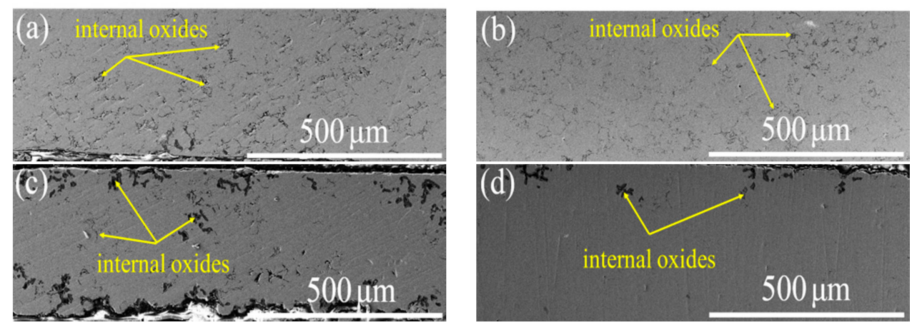

Figure 6. Microstructure of coatings after 21 h oxidation. (a) As-sprayed; (b) VHT1000; (c) VHT1100; and (d) VHT1200.

Table 5. Oxygen content in the as-sprayed coating and VHT coatings (wt.\%).

\begin{tabular}{ccccc}
\hline Coating & As-Sprayed & VHT1000 & VHT1100 & VHT1200 \\
\hline Oxygen content & 4.28 & 4.04 & 3.50 & 1.93 \\
\hline
\end{tabular}

Figure 7 shows TGO on the surface of oxide samples. TGO layers were generated on the surface of the as-sprayed coating and VHT coatings. The TGO thickness of the as-sprayed coating is about $8 \mu \mathrm{m}$. The TGO thickness of all three VHT coatings is about $5 \mu \mathrm{m}$.
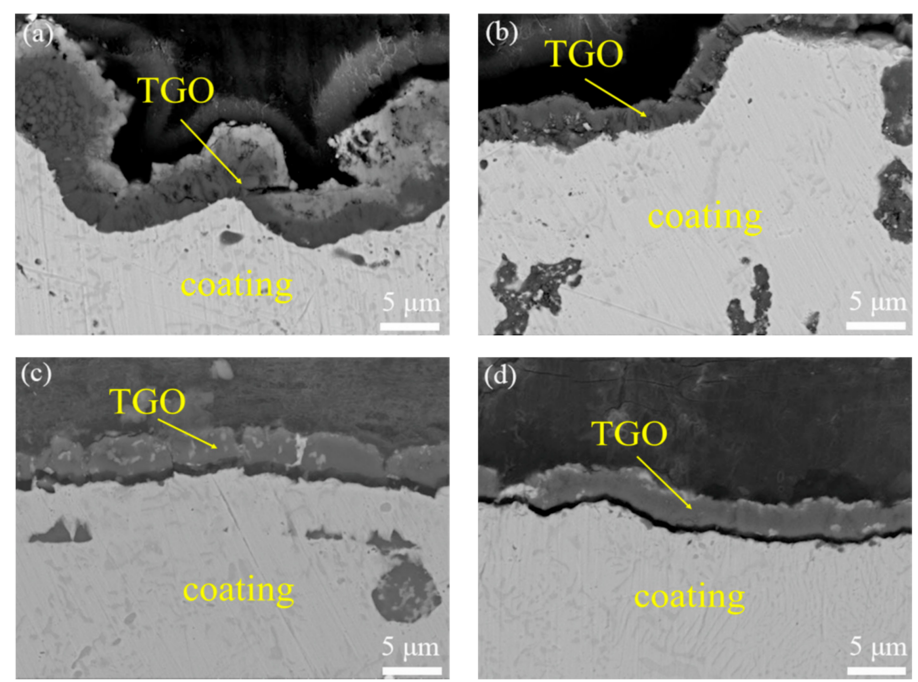

Figure 7. Structure of thermally grown oxide (TGO) on the surface of the original and vacuum heat-treated coatings after oxidation. (a) As-sprayed; (b) VHT1000; (c) VHT1100; and (d) VHT1200. 
Figure 8 presents the surface oxide morphology of TGO on the samples. The as-sprayed and VHT coatings exhibited different oxide morphologies. The as-sprayed coating was covered with a whisker-like oxide. The surface layer of the coatings was uniformly covered by a dark granular oxide after VHT at 1000 and $1100{ }^{\circ} \mathrm{C}$. The white particles on the surface of VHT1000 and VHT1100 were tested by EDS, the results show that these particles were $\mathrm{Cr}_{2} \mathrm{O}_{3}$. According to the following XRD results, these two oxides with different morphologies were both $\alpha-\mathrm{Al}_{2} \mathrm{O}_{3}$. The $1200{ }^{\circ} \mathrm{C}$ heat-treated coating was covered with two layers of granular oxide, in which the upper bright granular oxide was scattered over the layer of dark granular oxide (Figure 8d,h). The composition of these two oxides was tested by EDS, and the results show that the bright granular oxide is Y-rich $\alpha-\mathrm{Al}_{2} \mathrm{O}_{3}$ and the dark granular oxide is $\alpha-\mathrm{Al}_{2} \mathrm{O}_{3}$.
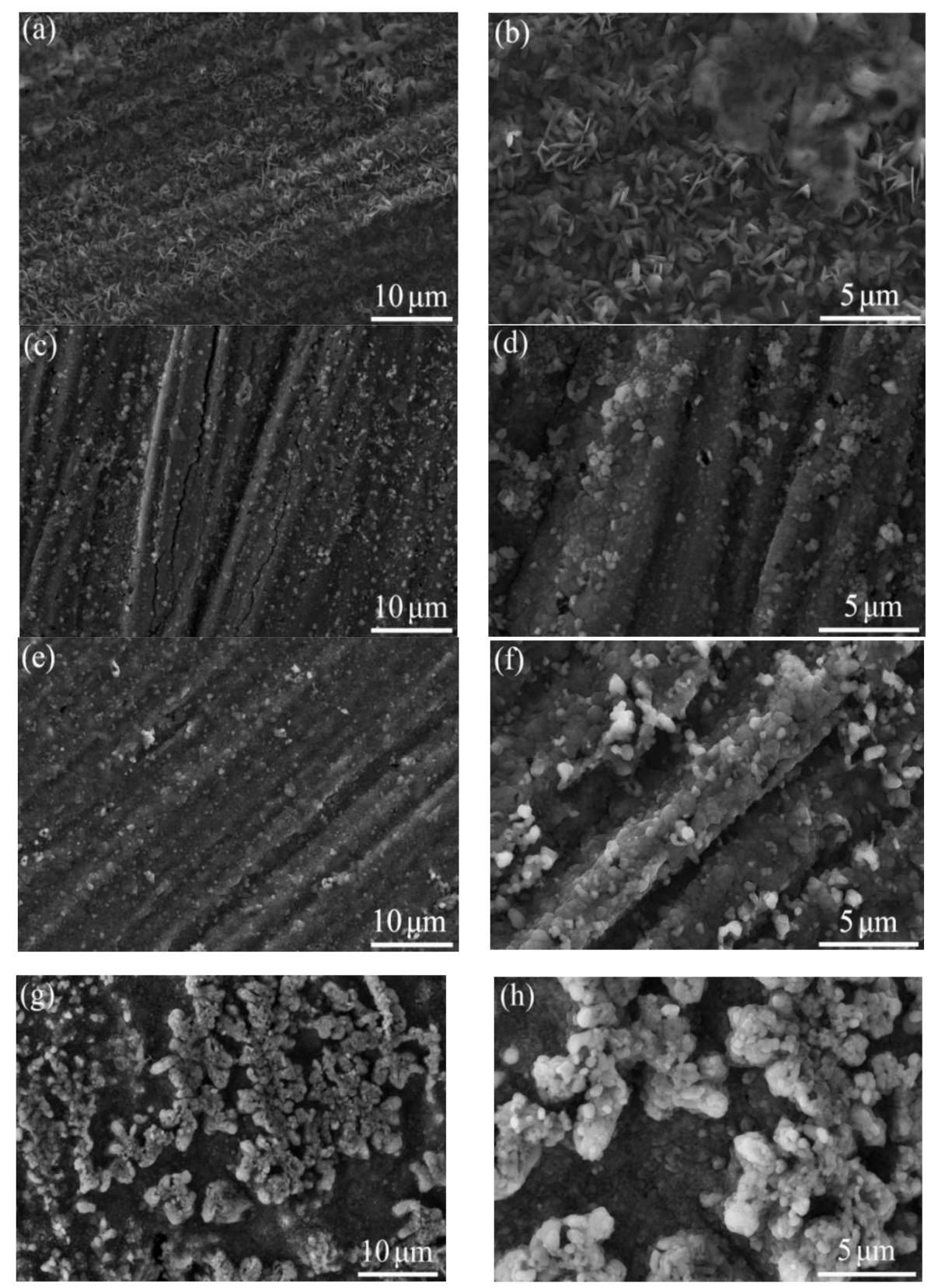

Figure 8. Morphology of oxide on the surface of the coatings. (a,b) As-sprayed, (c,d) VHT1000, (e,f) VHT1100, and (g,h) VHT1200. 


\subsection{XRD and EDS Analysis of Coatings}

Figure 9 presents the XRD results of the as-sprayed and VHT coatings. The phase composition of the as-sprayed coating consisted of $\gamma-\mathrm{NiCr}$ and $\beta-\mathrm{NiAl}$ phases. After heat treatment at different temperatures in a vacuum furnace, the VHT coatings had new diffraction peaks of $\gamma^{\prime}-\mathrm{Ni}_{3} \mathrm{Al}$.

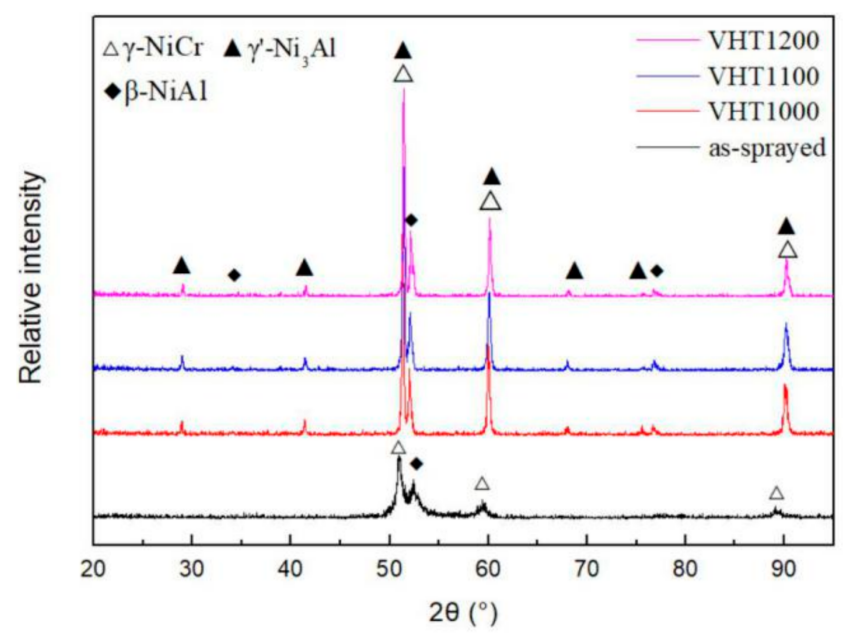

Figure 9. XRD results of the as-sprayed and heat-treated coatings.

The XRD results after the oxidation of the as-sprayed and VHT coatings (Figure 10) showed that the diffraction peak of $\alpha-\mathrm{Al}_{2} \mathrm{O}_{3}$ appeared in the oxidized coatings. The diffraction of $\theta-\mathrm{Al}_{2} \mathrm{O}_{3}$ was not observed in the as-sprayed coating.

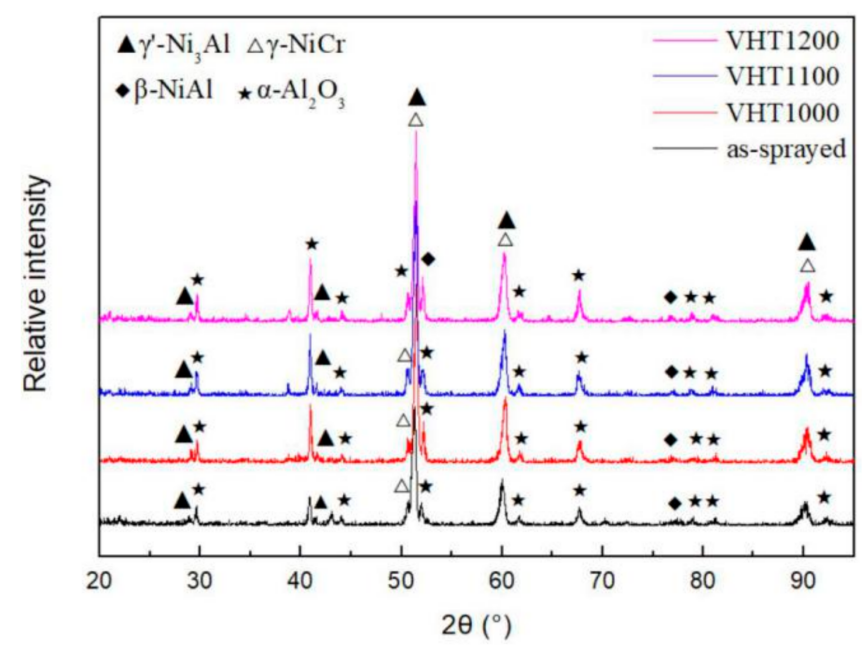

Figure 10. XRD results of the as-sprayed and heat-treated coatings after the oxidation test.

The element components on the surface of the coatings can affect the growth of TGO. After VHT processing, some coating elements were diffused on the surface of the coatings. However, the diffusion of the elements was affected by the microstructure. Therefore, the element components on the surface of the as-sprayed coating and VHT coatings were different. Table 6 shows the element components of the coatings' surface. The contents of $\mathrm{Al}$ and $\mathrm{Y}$ on the coatings' surface increased after VHT. When the vacuum heat temperature increased, the $Y$ content on the coatings' surface increased continuously. 
Table 6. Analysis of element components on the surfaces of the as-sprayed coating and VHT coatings (wt.\%).

\begin{tabular}{ccccc}
\hline Element & As-Sprayed & VHT1000 & VHT1100 & VHT1200 \\
\hline $\mathrm{O}$ & 2.86 & 10.88 & 13.40 & 5.76 \\
$\mathrm{Al}$ & 10.06 & 13.31 & 15.04 & 12.06 \\
$\mathrm{Cr}$ & 22.22 & 31.08 & 26.61 & 18.43 \\
$\mathrm{Ni}$ & 63.86 & 42.67 & 42.28 & 59.02 \\
$\mathrm{Y}$ & 1.00 & 2.07 & 2.66 & 4.73 \\
\hline
\end{tabular}

\section{Discussion}

The comparison of Figures 3 and 4a showed no evident change in the microstructure of powders and unmelted particles in the as-sprayed coating. This finding was mainly due to the fast powder feeding speed and low spraying temperature during the HVOF spraying [9] and the powder contact with the substrate surface without complete melting. Therefore, the as-sprayed coating was formed by incompletely melted particles, and the powder microstructure was preserved [1].

VHT coatings presented different microstructures (Figure $4 \mathrm{~b}-\mathrm{d}$ ). The appearance of dispersed irregular block $\beta-\mathrm{NiAl}$ could be attributed to the diffusion and the grain growth during VHT $[9,19]$. At the cooling stage of $\operatorname{VHT}\left(<950^{\circ} \mathrm{C}\right)$, the phase transformation of $\gamma+\beta \rightarrow \gamma^{\prime}+\alpha$ was conducted $[20,21]$. Therefore, $\gamma^{\prime}-\mathrm{Ni}_{3} \mathrm{Al}$ was generated in VHT coatings (Figures 4 and 9). The great number of grain/phase boundaries provides numerous fast diffusion paths of aluminum and therefore benefits the establishment of an exclusive $\mathrm{Al}_{2} \mathrm{O}_{3}$ scale [22]. The large amount of lamellar and granular $\gamma^{\prime}-\mathrm{Ni}_{3} \mathrm{Al}$ in $\mathrm{VHT}$ coatings provides plenty of phase boundaries and promotes the establishment of an $\mathrm{Al}_{2} \mathrm{O}_{3}$ scale. VHT resulted in a reduction in porosity levels in the as-sprayed coating. This reduction was due to diffusion, which decreased the porosity via a sintering effect $[6,23]$. The high defect concentration within the coating acted as "easy passages" for oxygen diffusion into the coating, and the internal oxides were rapidly formed in the initial stage of oxidation [24]. Thus, low porosity is beneficial to the oxidation resistance of NiCrAlY coatings. This point could be proven by Figure 6. The compact microstructure of VHT1200 coatings obviously contain less internal oxide (Figure 6d), which means better oxidation resistance.

The composition of TGO is related to oxidation resistance. An exclusive $\alpha-\mathrm{Al}_{2} \mathrm{O}_{3}$ scale ensures a good oxidation resistance. $\theta-\mathrm{Al}_{2} \mathrm{O}_{3}$ is a type of metastable alumina. It will convert into $\alpha-\mathrm{Al}_{2} \mathrm{O}_{3}$ during the oxidation process. $\theta-\mathrm{Al}_{2} \mathrm{O}_{3}$ is minimally protective against oxidation for two reasons. One is that the high growth rate of $\theta-\mathrm{Al}_{2} \mathrm{O}_{3}$ accelerates the consumption of aluminum [25]. The other is the volume expansion caused by the transformation of $\theta-\alpha$ may lead to a crack in TGO [18]. The reason why XRD did not detect the $\theta-\mathrm{Al}_{2} \mathrm{O}_{3}$ could because the transformation of $\theta-\alpha$ had been completed after the oxidation test $[26,27]$. However, the morphology of $\theta-\mathrm{Al}_{2} \mathrm{O}_{3}$ is similar to whiskers, and the whisker-like oxide will be preserved on the surface of $\alpha-\mathrm{Al}_{2} \mathrm{O}_{3}$ after the transformation of $\theta-\alpha[25,28-30]$. Hence, we inferred that the surface of the coatings did not generate $\theta-\mathrm{Al}_{2} \mathrm{O}_{3}$ after VHT but directly generated $\alpha-\mathrm{Al}_{2} \mathrm{O}_{3}$. No $\theta-\mathrm{Al}_{2} \mathrm{O}_{3}$ grew on the surface of VHT coatings (Figure 8), probably because of the microstructure and the concentration of yttrium during VHT. The reason could be concluded as follows. During the oxidation test, the following reactions can occur at the high temperature stage $\left(>1000^{\circ} \mathrm{C}\right)$ in VHT coatings $[15,17,19]$ :

$$
\gamma^{\prime}-\mathrm{Ni}_{3} \mathrm{Al} \rightarrow 3 \gamma-\mathrm{Ni}+\mathrm{Al}
$$

Hence, the $\gamma^{\prime}-\mathrm{Ni}_{3} \mathrm{Al}$ in VHT coatings will completely transform to $\gamma-\mathrm{NiCr}$ in the early stage of the oxidation test. This result suggests that VHT coatings contain more $\gamma$-NiCr. Relevant studies $[9,12]$ have shown that $\gamma-\mathrm{NiCr}$ tends to form a uniform oxide layer of $\alpha-\mathrm{Al}_{2} \mathrm{O}_{3}$ and $\beta-\mathrm{NiAl}$ tends to form $\theta-\mathrm{Al}_{2} \mathrm{O}_{3}$. Therefore, the aluminum and $\gamma-\mathrm{NiCr}$ produced by this reaction promote the generation of an exclusive $\alpha-\mathrm{Al}_{2} \mathrm{O}_{3}$ scale. Meanwhile, dispersed $\beta$-NiAl prevented continuous $\theta-\mathrm{Al}_{2} \mathrm{O}_{3}$ scale being generated on the VHT coatings' surface. The formation of $\theta-\mathrm{Al}_{2} \mathrm{O}_{3}$ can also be reduced by yttrium [14]. 
High temperature enhances the concentration of yttrium from the coating surface (Table 6), which prevented the generation of $\theta-\mathrm{Al}_{2} \mathrm{O}_{3}$.

Figure 6 presents the order of mass gain as follows: as-sprayed $>$ VHT1000 $>$ VHT1100 $>$ VHT1200. Combined with the above discussion, the following results can be concluded. The mass gain of the as-sprayed coating was maximum, which means the worst oxidation. The low content of yttrium and high concentration of $\beta-\mathrm{NiAl}$ caused the generation of continuous $\theta-\mathrm{Al}_{2} \mathrm{O}_{3}$ scale on the surface of the as-sprayed coating (Figure $8 \mathrm{a}, \mathrm{b}$ ). The rapid growth rate of $\theta-\mathrm{Al}_{2} \mathrm{O}_{3}$ caused the thickest TGO of the as-sprayed coating (Figure 7a). The unprotected $\theta-\mathrm{Al}_{2} \mathrm{O}_{3}$ layer and high porosity made oxide diffusion in the as-sprayed coating easy and caused serious internal oxidation (Figure 6a). VHT1200 presented minor mass gains because of the following reasons. (1) The $\gamma^{\prime}-\mathrm{Ni}_{3} \mathrm{Al}$ generated in the coating during VHT promotes the establishment of $\alpha-\mathrm{Al}_{2} \mathrm{O}_{3}$ scale. (2) The dispersion distribution of $\beta$-NiAl and the concentration of yttrium on the coatings' surface restrained the $\theta-\mathrm{Al}_{2} \mathrm{O}_{3}$ generated on the coatings' surface. (3) The extremely low porosity made it difficult for oxygen to enter the coatings and decreased the internal oxidation.

\section{Conclusions}

In this study, NiCrAlY coatings were prepared via HVOF spraying and VHT was carried out at different temperatures. Then, high temperature oxidation resistance was compared. The conclusions were as follows:

Compared with the as-sprayed, VHT1000 and VHT1100 coatings, the VHT1200 coating has the best high temperature oxidation resistance, which is related to the microstructure transformation under different VHT temperature conditions. After VHT, the $\gamma^{\prime}-\mathrm{Ni}_{3} \mathrm{Al}$ phase appears in the coating, and with the increase in VHT temperature, more $\gamma^{\prime}-\mathrm{Ni}_{3} \mathrm{Al}$ phase boundaries promote the formation of $\alpha-\mathrm{Al}_{2} \mathrm{O}_{3}$. On the other hand, the concentration of yttrium and the phase transformation of $\gamma^{\prime}-\mathrm{Ni}_{3} \mathrm{Al} \rightarrow \gamma-\mathrm{NiCr}$ on the surface of VHT1200 prevents the generation of $\theta-\mathrm{Al}_{2} \mathrm{O}_{3}$. In addition, VHT is beneficial for reducing the porosity of the coating, and the VHT1200 coating has the lowest internal oxidation.

Author Contributions: Conceptualization, J.Z. and D.Y.; methodology, J.Z. and D.Y.; software, J.Z.; validation, J.Z. and D.Y.; formal analysis, J.Z.; investigation, J.Z. and D.Y.; resources, D.Y. and Y.G.; data curation, J.Z.; writing—original draft preparation, J.Z.; writing—review and editing, J.Z. and D.Y.; visualization, J.Z.; supervision, D.Y. and Y.G.; project administration, D.Y. and Y.G.; funding acquisition, D.Y. and Y.G. All authors have read and agreed to the published version of the manuscript.

Funding: This work was supported by the Fundamental Research Funds for the Central Universities of China (3132019169), the Projects for Dalian Youth Star of Science and Technology (2018RQ53), and the Natural Science Foundation of Liaoning Province (20170540084).

Conflicts of Interest: The authors declare no conflict of interest.

\section{References}

1. Saeidi, S.; Voisey, K.; McCartney, D.G.; McCartney, D. The effect of heat treatment on the oxidation behavior of HVOF and VPS CoNiCrAlY Coatings. J. Therm. Spray Technol. 2009, 18, 209-216. [CrossRef]

2. Tang, F.; Ajdelsztajn, L.; Schoenung, J.M. Characterization of oxide scales formed on HVOF NiCrAlY coatings with various oxygen contents introduced during thermal spraying. Scr. Mater. 2004, 51, 25-29. [CrossRef]

3. Zhang, G.; Kanta, A.F.; Li, W.; Liao, H.; Coddet, C. Characterizations of AMT-200 HVOF NiCrAlY coatings. Mater. Des. 2009, 30, 622-627. [CrossRef]

4. Naeimi, F.; Rahimipour, M.R.; Salehi, M. Effect of sandblasting process on the oxidation behavior of HVOF MCrAlY coatings. Oxid. Met. 2016, 86, 59-73. [CrossRef]

5. Chen, H.; Si, Y.; McCartney, D.; McCartney, D. An analytical approach to the $\beta$-phase coarsening behaviour in a thermally sprayed CoNiCrAlY bond coat alloy. J. Alloys Compd. 2017, 704, 359-365. [CrossRef]

6. Saeidi, S.; Voisey, K.; McCartney, D.G. Mechanical properties and microstructure of VPS and HVOF CoNiCrAlY coatings. J. Therm. Spray Technol. 2011, 20, 1231-1243. [CrossRef]

7. Liu, J.M.; Yu, Y.G.; Ren, X.J.; Zhang, D.M.; Shen, J. Comparative study of the cyclic oxidation resistance of NiCrAlY and NiCoCrAlY coatings. Adv. Mater. Res. 2013, 1810-1813. [CrossRef] 
8. Li, B.; Gao, Y.; Li, C.; Zheng, Q.; Liu, Z.; Li, Y.; Jia, J. Mechanical, tribological and oxidation resistance properties of Ni-based self-lubricating composite coatings at elevated temperature by APS. Int. J. Mater. Res. 2018, 109, 858-864. [CrossRef]

9. Doolabi, D.S.; Rahimipour, M.R.; Alizadeh, M.; Pouladi, S.; Hadavi, S.M.M.; Vaezi, M. Effect of high vacuum heat treatment on microstructure and cyclic oxidation resistance of HVOF-CoNiCrAlY coatings. Vacuum 2017, 135, 22-33. [CrossRef]

10. Han, Y.; Zhu, Z.; Zhang, B.; Chu, Y.; Zhang, Y.; Fan, J. Effects of process parameters of vacuum pre-oxidation on the microstructural evolution of CoCrAlY coating deposited by HVOF. J. Alloys Compd. 2018, 735, 547-559. [CrossRef]

11. Sloof, W.G.; Nijdam, T.J. On the high-temperature oxidation of MCrAlY coatings. Int. J. Mater. Res. 2009, 100, 1318-1330. [CrossRef]

12. Levi, C.G.; Sommer, E.; Terry, S.G.; Catanoiu, A.; Rühle, M. Alumina grown during deposition of thermal barrier coatings on NiCrAlY. J. Am. Ceram. Soc. 2003, 86, 676-685. [CrossRef]

13. An, T.F.; Guan, H.R.; Sun, X.F.; Hu, Z.Q. Effect of the $\theta-\alpha-\mathrm{Al}_{2} \mathrm{O}_{3}$ transformation in scales on the oxidation behavior of a nickel-base superalloy with an aluminide diffusion coating. Oxid. Met. 2000, 54, 301-316. [CrossRef]

14. Grabke, H.J. Oxidation of NiAl and FeAl. Intermetallics 1999, 7, 1153-1158. [CrossRef]

15. Pérez, E.S.; Gutierrez, H.M.; López, F.J. Corrosion of MCrAlY: Pt composites prepared by spark plasma sintering. Corros. Eng. Sci. Technol. 2018, 53, 539-548. [CrossRef]

16. Zhou, S.; Xiong, Z.; Lei, J.; Dai, X.; Zhang, T.; Wang, C.; Shengfeng, Z. Influence of milling time on the microstructure evolution and oxidation behavior of NiCrAlY coatings by laser induction hybrid cladding. Corros. Sci. 2016, 103, 105-116. [CrossRef]

17. Schulz, U.; Bernardi, O.; Ebach-Stahl, A.; Vassen, R.; Sebold, D. Improvement of EB-PVD thermal barrier coatings by treatments of a vacuum plasma-sprayed bond coat. Surf. Coat. Technol. 2008, 203, 160-170. [CrossRef]

18. Zhu, C.; Javed, A.; Li, P.; Liang, G.; Xiao, P. Study of the effect of laser treatment on the initial oxidation behaviour of Al-coated NiCrAlY bond-coat. Surf. Interface Anal. 2013, 45, 1680-1689. [CrossRef]

19. Schab, C.; Zimmermann, J.R.A.; Grasso, P.-D.; Stankowski, A.; Heinze, S.; Marquardt, A.; Leyens, C. Thermodynamic calculation and experimental analysis of critical phase transformations in HVOF-sprayed NiCrAlY-coating alloys. Surf. Coat. Technol. 2019, 357, 924-938. [CrossRef]

20. Song, J.; Ma, K.; Li, Y.; Zhang, L.; Schoenung, J.M. High temperature microstructure and microhardness evolution in dense NiCrAlY bulk material fabricated by spark plasma sintering. Mater. Sci. Eng. A 2011, 528, 3210-3217. [CrossRef]

21. Achar, D.; Munoz-Arroyo, R.; Singheiser, L.; Quadakkers, W.J. Modelling of phase equilibria in MCrAlY coating systems. Surf. Coat. Technol. 2004, 187, 272-283. [CrossRef]

22. Zhao, L.R.; Lupandina, O.; Pankov, V.V.; McKellar, R.C. Microstructures of NiCrAlY coating applied on CMSX-4 by cathodic arc deposition. Struct. Dyn. 2014, 7, 1-8. [CrossRef]

23. Li, B.; Ma, S.; Gao, Y.; Li, C.; Guo, H.; Zheng, Q.; Kang, Y.; Jia, J. Mechanical, tribological, and oxidation resistance properties of NiCrAlY coating by atmospheric plasma spraying. Front. Mater. 2019, 6, 1-9. [CrossRef]

24. Khakzadian, J.; Hosseini, S.; Madar, K.Z. Cathodic arc deposition of NiCrAlY coating: Oxidation behaviour and thermodynamic. Surf. Eng. 2019, 35, 677-682. [CrossRef]

25. Tolpygo, V.; Clarke, D. Microstructural study of the theta-alpha transformation in alumina scales formed on nickel-aluminides. Mater. High Temp. 2000, 17, 59-70. [CrossRef]

26. Yang, S.; Wang, F. Effect of microcrystallization on the oxidation behavior of $\beta-\mathrm{NiAl}$ at $1000{ }^{\circ} \mathrm{C}$ in air. Jinshu Xuebao/Acta Metall. Sin. 2000, 36, 511-516.

27. Li, M.; Zhang, Z.; Sun, X.; Li, J.; Yin, F.; Hu, W.; Guan, H.; Hu, Z. Oxidation behavior of sputter-deposited NiCrAlY coating. Surf. Coat. Technol. 2003, 165, 241-247. [CrossRef]

28. Zhu, C.; Li, P.; Wu, X. A study of the diffusion and pre-oxidation treatment on the formation of $\mathrm{Al}_{2} \mathrm{O}_{3}$ ceramic scale on NiCrAlY bond-coat during initial oxidation process. Ceram. Int. 2016, 42, 7708-7716. [CrossRef]

29. Bai, M.; Song, B.; Reddy, L.; Hussain, T. Preparation of $\mathrm{MCrAlY}-\mathrm{Al}_{2} \mathrm{O}_{3}$ composite coatings with enhanced oxidation resistance through a novel powder manufacturing process. J. Therm. Spray Technol. 2019, 28, 433-443. [CrossRef] 
30. Ma, K.; Schoenung, J.M. Isothermal oxidation behavior of cryomilled NiCrAlY bond coat: Homogeneity and growth rate of TGO. Surf. Coat. Technol. 2011, 205, 5178-5185. [CrossRef]

Publisher's Note: MDPI stays neutral with regard to jurisdictional claims in published maps and institutional affiliations.

(C) 2020 by the authors. Licensee MDPI, Basel, Switzerland. This article is an open access article distributed under the terms and conditions of the Creative Commons Attribution (CC BY) license (http://creativecommons.org/licenses/by/4.0/). 